Transactions of the RHS $3 \mathrm{I}$ (202I), pp. 49-73 C) The Author(s), 202I. Published by Cambridge University Press on behalf of the Royal Historical Society. This is an Open Access article, distributed under the terms of the Creative Commons Attribution-NonCommercialNoDerivatives licence (https://creativecommons.org/licenses/by-nc-nd/4.o/), which permits non-commercial re-use, distribution, and reproduction in any medium, provided the original work is unaltered and is properly cited. The written permission of Cambridge University Press must be obtained for commercial re-use or in order to create a derivative work. doi:I0.1017/Soo80440121000037

\title{
BAROQUE AROUND THE CLOCK: DANIELLO BARTOLI SJ (I608-I685) AND THE USES OF GLOBAL HISTORY*
}

\section{By Simon Ditchfield}

READ I8 SEPTEMBER 2020

\begin{abstract}
Right from its foundation in 1540 , the Society of Jesus recognised the value and role of visual description (ekphrasis) in the persuasive rhetoric of Jesuit missionary accounts. Over a century later, when Jesuit missions were to be found on all the inhabited continents of the world then known to Europeans, descriptions of the new-found lands were being read for the entertainment as well as the edification of their Old World audiences. The first official history of the Society's missions in the vernacular, the volumes authored by Daniello Bartoli (I608-I685), played an important role in communicating a sense of the distinctiveness of the order's global mission. Referred to by Giacomo Leopardi (I798-1837) as the 'Dante of baroque prose', Bartoli developed a particularly variegated and intensely visual idiom to meet the challenge of describing parts of the world which the majority of his readers, including himself, would never visit.
\end{abstract}

There has never been a better time to write about the history of the Jesuits. As the footnotes to this paper demonstrate, the last twenty years or so, in particular, has seen a renaissance in the study not only of the old (pre-suppression) Society but also of the order after its refounding in I8I4. This has culminated in the recent publication of two major reference works, by Cambridge and Oxford University Presses, in 2017 and 2019 respectively. ${ }^{1}$ Although not a few of the scholars who have

* For John O'Malley, in gratitude and affection, on his ninety-fourth birthday.

The Cambridge Encyclopedia of the Jesuits, ed. Thomas Worcester (Cambridge, 20I7); The Oxford Handbook of the Fesuits, ed. Ines G. Županov (Oxford, 2019). The 'opening out' of Jesuit studies to non-Jesuits is widely accepted to have begun with the first of two big conferences on the Society hosted by Boston College in 1997, which issued in the volume of proceedings, Fesuits: Cultures, Arts and the Sciences, I540-I773, ed. J. W. O'Malley et al. (Toronto, Buffalo and London, 1999). See the reflections on the proceedings made by Luce Giard (ibid., 709-1o), who used the more resonant French term 'désenclavement'. 
played (and continue to play) an active and distinguished part in this revival are themselves members of the Society, including the dedicatee of this paper, the field of Jesuit studies is now a genuinely ecumenical enterprise, open to scholars both religious and lay, from all disciplines, who work in all four corners of the globe, as befits a religious order that, as this paper goes on to discuss, has contributed in such fundamental ways to meeting the challenge for people of European heritage of discovering how to describe a vastly expanded world in the early modern period. The Jesuits were careful to write their own history from the very beginning of their existence, starting with the so-called 'autobiography' of their founder (which was actually written up from memory by Luis Gonçalves da Camara at the end of each day during which he had been listening to Ignatius give an account of his life ${ }^{2}$.

So when the focus of this essay, Daniello Bartoli, put pen to paper he was already heir to a rich tradition. However, it was a largely latinate tradition, and he was the first to offer a vernacular account which, on the one hand, enjoyed official status and, on the other, covered those parts of the globe where the Jesuit missionaries had either distinguished themselves mainly through heroic defeat and martyrdom - namely Asia (India, Southeast Asia and Japan) and England - or as in China showed themselves to be, at least on the Jesuits' own account, superior to even the Confucian-educated elite. Bartoli created a rich resource to inspire his confreres when read out loud at refectories in the Italian peninsula and beyond, or as a prose model to be borrowed by preachers, imitated by hagiographers or simply to be admired and copied (and maybe even translated into Latin) by students attending the dense network of Jesuit colleges for at least two centuries after Bartoli's death. ${ }^{3}$

\section{I}

Sir, here is what I promised you. Here is the first outline of the morality of the good Jesuit fathers, 'these men, outstanding in doctrine and in wisdom, who are guided by divine wisdom which is more certain than all philosophy, which is more infallible than all the rules of philosophy.' You may think that I am joking, but I say this quite seriously, or rather they say it themselves. I am simply copying down their own words, in their

${ }^{2}$ For this reason, the editor of the latest edition in English translation stops calling this work an 'autobiography' and instead gives it the following title: A Pilgrim's Testament: The Memoirs of St Ignatius of Loyola, ed. Barton T. Geger (Boston, MA, 2020). My thanks to Dr Thomas Flowers SJ for alerting me to this important detail.

3 That Bartoli's work was still deemed relevant and commercially viable after the restoration of the Society in I8I4, at least in the Italian peninsula, can be seen by the edition of his complete works in thirty-four octavo volumes printed in Turin by Giacinto Marietti (1825-43), whose first eighteen volumes consisted of the Istoria, published all together in I825. There is no extant evidence to suggest that Bartoli ever began work on the volumes of the Istoria which would have covered the Americas. 
work entitled, Imago primi saeculi. I am only transcribing from them and from the close of their Elogium. 'This is the society of men, or rather of angels, predicted by Isaiah in these words: "Go, ye angels, prompt and swift of wing."' Is not the prophecy, as applicable to them, clear? 'They are eagle-spirits; they are a flight of phoenixes (for a recent author has shown that there is more than one phoenix). They have changed the face of Christendom.' Since they assert all this, we are bound to believe them. ${ }^{4}$

In this way, the French philosopher Blaise Pascal (I623-I662) put his finger on a problem that has not gone away in the intervening centuries: are we bound to believe the Jesuits' account of their own history and achievements?5 The immediate occasion for Pascal's coruscating wit was his defence of the Jansenist Antoine Arnauld (I6I2-I694), and the quotation is taken from the opening lines of the fifth provincial letter, dated 20 March i656. Pascal was himself quoting from that great monument to Jesuit pride, as well as to the arts of engraving and Latin encomia, which was the 952-folio-page Image of the First Century (Imago Primi Saeculi) published by the Flandro-Belgian province to accompany celebration of their first centenary in 1640 and embellished with no fewer than 127 emblems. ${ }^{6}$ The emblem that perhaps more than any other emphasises the global scope of Jesuit missionary ambition is 'One world is not enough' (Unus non sufficit orbis) (Figure I).7 It has its counterpart in the frontispiece to the second edition of the opening volume of the first vernacular history of the Society's founder, the Basque nobleman and knight Ignatius of Loyola (c.149I-I556), by the subject of this article, the Ferrarese Jesuit Daniello Bartoli (I608-I685). ${ }^{8}$. Bartoli's approach to his subject was faithfully represented in the work's distinctive title, Della Vita e del Istituto di S. Ignazio fondatore della Compagnia di Giesu ('The Life and Order/Rule of Life of St Ignatius, founder of the Company of Jesus'), and its frontispiece in which

4 Blaise Pascal, The Provincial Letters, trans. A. J. Krailsheimer (Harmondworth, 1967), 74. I have slightly adapted Krailsheimer's translation. My reference text has been the Flammarion edition with notes by Antoine Adam: Lettres écrites à un provincial (Paris, 1967), 73.

5 'Il le faut croire puis qu'ils le disent', Lettres, 73.

${ }^{6}$ Imago Primi Saeculi Societatis Iesu a Provincia Flandro-Belgica eiusdem Societatis Repraesenta (Antwerp, I640).

7 Ibid., 326.

8 The first published history of the Society was the two Latin volumes by Niccolò Orlandini (who died in I6o6), which were completed by Franceso Sacchini and published in I6I4 and I62I. The first of these was, in turn, heavily dependent on Juan Alfonso de Polanco's account of the life of Ignatius and the activities of the Society in the period I537-56, the Chronicon Societatis Iesu, which remained unpublished until the six-volume edition in the Monumenta Historica Societatis Iesu series (Madrid, I894-8). Sacchini took the story down to Ignatius's successor, Superior General Diego Laínez (in office I558-65). Sacchini also contributed to volume 3 , which was published only in I649. This covered the period ${ }_{5} 6_{4}-72$. Volume 4 followed three years later, in 1652 , and covered the period $1572-80$. The first part of volume $5(1580-90)$ was revised by Pierre Poussines and published in I66I. 


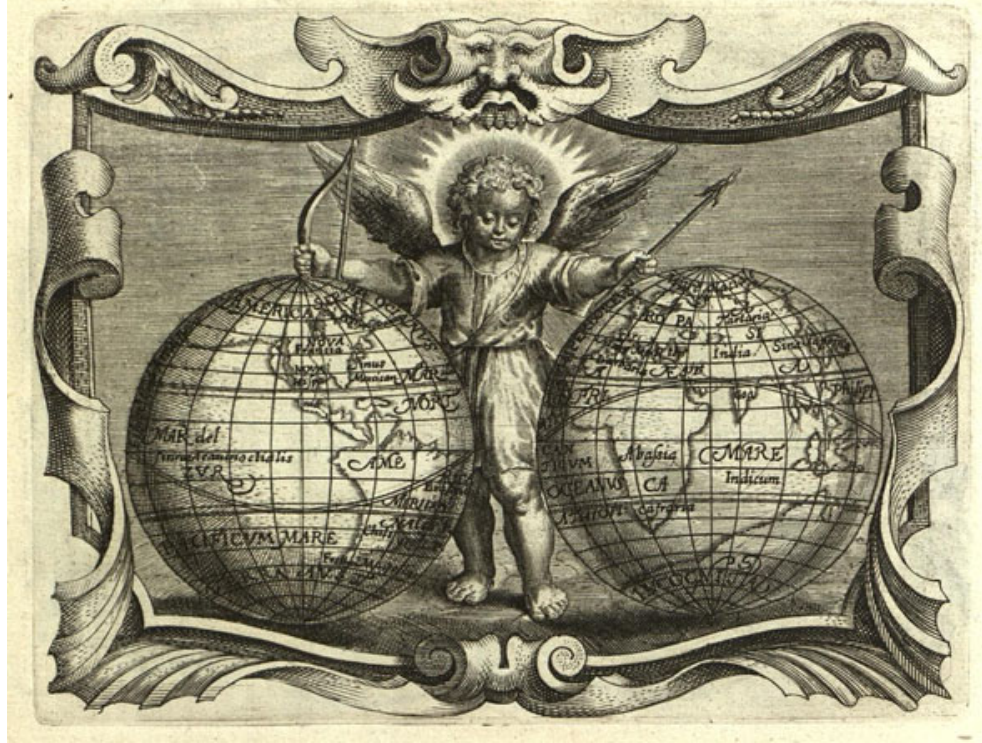

Figure I. Unus non sufficit orbis (One world is not enough). Taken from Imago primi saeculi Societatis Iesu a Prouincia Flandro-Belgica euisdem Societatis repreasentata (Antwerp: Ex officina Plantiniana Balthasaris Moreti, I640), 326. Image courtesy of the Pius XII Memorial Library, St Louis.

Ignatius has become the very symbol and embodiment of a religious order which directs the divine illumination from the fixed stars (Figure 2). Not for nothing had Bartoli been taught by the most brilliant anti-Copernican of the seventeenth century, his fellow Jesuit and Ferarrese Giovanni Battista Riccioli (I598-I67I), so that Ignatius shone - or as Bartoli puts it in the note to the reader 'sounded' (Ignatium sonant) - throughout the world by reaching all four parts of the globe represented here by personifications of Africa, Asia, Europe and the Americas.

\section{II}

On the very first page of the address to the reader of the first edition of this work, Bartoli noted how the foundation and progress of the Society could be mapped onto the entire known world: Spain being the place of Ignatius's birth; France of his education, together with that of his first companions, at the Sorbonne in Paris; Italy as the location of the Society's foundation by Pope Paul III; Portugal as the site of preparations for its first overseas missions. Germany, meanwhile, witnessed the 


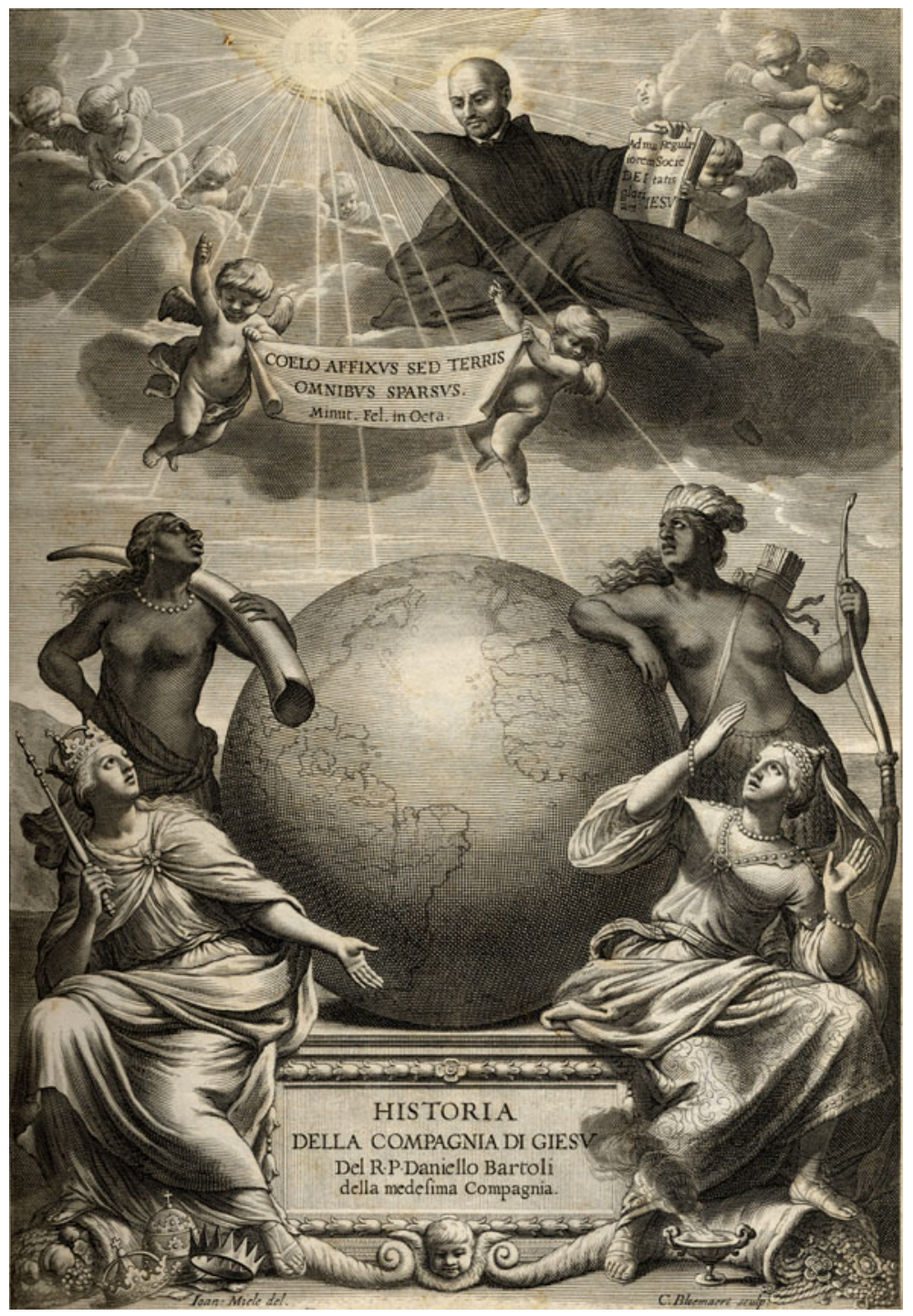

Figure 2. Historia della compagnia di Gesù del R.P. Daniello Bartoli della medesima compagnia. Anteportam by Jan Miel and Cornelis Bloemaert (Rome: de Lazzari, I659). Image courtesy of the Archivum Historicum Societatis Iesu (ARSI), Rome. 
order's first 'test of battle' (pruova d'armi) against the heresies of the age and, finally - Ignatius yet living - Africa together with the Spanish and Portuguese empires in the New World and East Indies saw the seeding of the Society's apostolate with the blood and sweat of its members.

This first volume of the history of the Society was also conceived from the outset as necessarily a polemic. As Bartoli put it, immediately after this passage, in his note to the reader:

This History will count for me as two: i.e. not only as a History but also as an Apology. For there is no shortage of pens and tongues [belonging not only] to innumerable heretics but also to a great number of Catholics, who in a thousand ways, in both writing and speech, attempt to make the Society despised by the world and held in public contempt. ${ }^{9}$

It is therefore appropriate that in two major, recently published reference works about the Society, there are substantial entries and chapters devoted to anti-Jesuitism not only as a movement but also as a literary genre. ${ }^{\text {Io }}$ Already by 1564 , eight years after Loyola's death, the Roman curialist and bishop Ascanio Cesarini had penned the pamphlet Novi advertimenti, which focused on the fact that the Society ignored the usual duties of religious orders by not singing or even saying their office in choir. ${ }^{I I}$ The lawyer Étienne Pasquier's Le Catechisme des Jésuites (I602) labelled the Jesuits as a 'hermaphrodite' order and accused them of being 'too little French', possessing 'two souls in their bodies. One Roman in Rome; the other French in France.' ${ }^{\prime 2}$ Undoubtedly the longest-lasting of such works was, in fact, an example of fesuit antiJesuitism: the Monita secreta (Secret Instructions), which claimed to contain secret advice that Jesuits gave to members in order to secure power, wealth and, ultimately, world domination. The author was an ex-Jesuit, Hieronim Zahorovsky, who came from Włodzimierz (in modern-day Ukraine), failed a theology exam and so was not admitted

9 'Varrammi ancora a doppio questa Historia; cioè non tanto per Historia, come per Apologia. Impercioche penne, e lingue non mancano, e d'heretici oltrenumero, e a gran numero di Catolici, che in mille form, scrivendo, e favellando, s'adoperan, secondo lor talento, per mettere in dispetto al mondo, e in publico vitupero la Compagnia ...' Second page of the 'A' Lettori' to Della vita e dell'istituto di S. Ignatio fondatore della compagnia di Giesu libri cinque del P. Daniello Bartoli della Medesima Compagnia (Rome, I650). My sincere thanks to Franco D'Intino for assistance with translating Bartoli's baroque prose.

Io 'Anti-Jesuit Polemic', in Cambridge Encyclopedia of the Jesuits, ed. Worcester, 30-5, and 'Anti-Jesuitism in a Global Perspective', in Oxford Handbook of the Jesuits, ed. Zuupanov, $833-54$.

${ }_{\text {II }}$ Sabina Pavone, 'The History of Anti-Jesuitism: National and Global Dimensions', in The Fesuits and Globalization: Historical Legacies and Contemporary Challenges, ed. Thomas Banchoff and José Casanova (Washington, DC, 2016), II I-30, at II2.

${ }^{\mathrm{I} 2}$ Etienne Pasquier, Le Catéchisme des fésuites ou examen de leur doctrine, ed. Claude Sutto (Québec, I982), I86r. A modern English translation of this work, by Patricia M. Ranum and co-edited by Robert A. Maryks and Jotham Parsons, is forthcoming from Brill: The Fesuits' Catechism or Their Doctrine Examined (I602). 
to the ranks of those who took, in addition to the vows of chastity, poverty and obedience, a fourth vow of special service to the pope with regard to missions, and thereby was excluded from becoming a fully professed member of the Society. ${ }^{13}$ The Monita was first printed in Kraków in I6I4 and enjoyed an exceptionally long afterlife, being most recently reprinted in Moscow in 1996. I4

To counter such works, in book 2 chapter 8 of his Vita e dell'Istituto di S. Ignatio, Bartoli urged the need for the Jesuits to be always on guard, as were the Israelites under Nehemiah when they rebuilt the walls of Jerusalem with one eye on their weapons nearby. ${ }^{15}$ He then proceeded to list a long catalogue of the different kinds of works which had been written against the Jesuits, including poetry, history, novels, newsletters, trials, satires, philippics and prophecies - 'enough to fill a more than modest library', as he put it - to which the most effective antidote, in Bartoli's view, was Pedro de Ribabaneira's printed catalogue of works written by the Jesuits, of 1602 , which had been revised and expanded by Philippe Alegambe in ${ }^{1} 643 \cdot{ }^{16}$ This is the ancestor of Carlos Sommervogel's twelve-volume bibliography and its online successor. ${ }^{17}$ This kind of reference work was not unique to the Jesuits - one thinks, for example, of Quétif and Echard's classic bibliography of Dominican authors, the Scriptores ordinis praedicatorum of 1719-2I - but the Society has, uniquely, kept up the tradition to the present day.

Bartoli in fact compared antipathy to the Society with the jealousy that the advent of such orders as the Dominicans and Franciscans had provoked in the thirteenth century, before listing a number of reasons (seven) why people might think badly of the Society. ${ }^{18}$ These included ignorance; the reading of books such as the Monita (which amounted to the same thing); blaming the whole order just because there were bad apples; and the malignity of apostates. However, the real heavy lifting carried out by Bartoli's volume was done in demonstrating, first, the orthodoxy of Loyola's most important writing, the Spiritual

${ }^{13}$ My sincere thanks, once again, to Dr Flowers for putting me right on this other important detail.

${ }^{{ }^{14}}$ Sabina Pavone, The Wily Fesuits and the 'Monita Secreta'. The Forged 'Secret Instructions' of the Fesuits: Myth and Reality (St Louis, 2005). See appendix 2 of this book for a list of the numerous editions (both printed and manuscript), $234^{-} 4^{2}$.

${ }^{15}$ Bartoli, Della Vita e dell'Istituto di S. Ignatio, i78.

${ }^{16}$ Bibliotheca Scriptorum Societatis Iesu, post excusum anno MDCVIII. Catalogum R. P. Pietri Ribadeneirae Societatis Eiusdem Theologi, nunc hoc novo apparatu librorum ad annum reparatae salutis MDCXLII editorum concinnata et illustrium vironum elogiis adornata, Philippo Alegambe Bruxellensi ex eadem societate Iesu accedit Catalogus Religiosorum Societatis Iesu (Antwerp, I643).

${ }^{17}$ Bibliothèque de la Compagnie de Fésus, 2nd edn (12 vols., Brussels and Paris, I89o-1932); Jesuit Bibliography Online hosted by Boston College, Massachusetts: https://jesuitonlinebibliography.bc.edu.

${ }^{18}$ Bartoli, Della Vita e dell'Istituto di S. Ignatio, I86-207 (bk II, chs. II-17). 
Exercises - which essentially offers a programme for a month's silent retreat, including various techniques of prayer supplemented by approaches to discernment of the retreatant's own spiritual state and so was suspected of promoting the heresy of illuminism free of clerical control; secondly, the Society's distinctiveness in not reciting the office in choir (which was a particular target of Cesarini's early polemic); and, thirdly, why the Society possessed several grades of membership fully professed priests (i.e. those who had taken the fourth vow of special obedience to the pope 'in regard to missions'), spiritual coadjutors (i.e. priested and therefore qualified to preach, teach and hear confession) and, finally, simple lay brothers, or, to give them their formal title, temporal coadjutors. ${ }^{19}$ Those who belonged to this last grade, who also took vows of poverty, chastity and obedience, constituted, together with the spiritual coadjutors, between a quarter and a third of those in any single community. ${ }^{20}$ Last but not least was Bartoli's emphasis on the significance of the fact that the first Jesuit companions had made their first vow of association on Montmartre and that martyrdom had subsequently become at once a symbol of the Society's legitimacy and a lieu de mémoire for subsequent historians and hagiographers of the order. Bartoli claimed that during the first century there had been at least 300 of his confreres who had lost their lives (the majority on the mission to Japan). His brief description leaves little to the imagination:

[They were martyred] [b]y being slowly burned for two or three hours; drowned at sea; torn apart; sliced up; pierced with spears; crucified; beheaded; killed by immersion in freezing or boiling water; poisoned; hanged or [killed] by means of the cruellest Japanese torture of being suspended upside down over a ditch until all one's blood had slowly drained out from incisions made behind each ear. ${ }^{21}$

When reading such passages, we need to remember how, not only for the Jesuits, history was essentially a polemical and rhetorical exercise and remained subordinate to rhetoric, being a reservoir of inventio, that is to say, telling and memorable examples to drive home a point. ${ }^{22}$ Moreover, as the art historian Helen Langdon has powerfully shown

${ }^{19}$ The grade of coadjutor is first mentioned in the revised Formula of the Institute of I550. See The Constitutions of the Society of Jesus and their Complementary Norms, ed. John W. Padberg (St Louis, I996), 3-I3, at 5 .

${ }^{20}$ Decree 82 para. 3 from the 6th General Congregation (I616), in For Matters of Greater Moment: The First Thirty Fesuit General Congregations, ed. J. Padberg, M. O'Keefe and J. McCarthy (St Louis, 1994), 275.

${ }^{21}$ Bartoli, Della Vita e dell'Istituto di S. Ignatio, I77.

${ }^{22}$ On the role of rhetoric in Bartoli's history of the Jesuits see Simon Ditchfield, 'The Limits of Erudition: Daniello Bartoli SJ (I608-I685) and the Mission of Writing History', in Confessionalisation and Erudition in Early Modern Europe: An Episode in the History of the Humanities, ed. Nicholas Hardy and Dmitri Levitin (Oxford, 20I9), 2I8-39 (in particular, $227-32)$. 
(and as I have argued elsewhere), Bartoli was the most visually aware of writers, a supreme ekphrasist, who provided direct inspiration for one of the most 'unorthodox and extravagant' painters of the Baroque, Salvator Rosa. ${ }^{23}$

\section{III}

Generally speaking, the Jesuits wrote and argued better, and more often than not were better informed and prepared about the points at issue, than most of their opponents, Pascal and a very few others excepted. This was owing to the existence of a centralised information network of unprecedented scale and geographical scope as well as of an education programme, the famous Ratio studiorum (Method of Study), which though only finalised in 1599 had been trialled for an extended period beforehand and gave its students astonishing facility in the arts of persuasion (and in the process educated a sizeable proportion of the male offspring of the European elite of both Catholic and Protestant persuasion until the suppression of the Old Society in I773) ${ }^{24}$ Robert Maryks has calculated that students in the Jesuit colleges spent some five hours a day, 270 days of the year, in the company of classical, almost exclusively Latin, authors, pre-eminently Cicero, as a way of honing their skills. ${ }^{25}$ Secondly, as we have seen, the Jesuits had plenty of opponents (including those within their own order), against whom to sharpen their quills. As Anthony Grafton taught us long ago (picking up on his teacher Arnaldo Momigliano's call to take notice of the contribution of antiquarians to the history of historical scholarship), polemic was a prodigious generator of erudition and scholarship in the age of humanism and of the Protestant and Catholic Reformations. Arguably, intra-Catholic squabbling had an even more profound and long-lasting impact. ${ }^{26}$

\footnotetext{
${ }^{23}$ Floriana Conte, Tra Napoli e Milano. Viaggi di artisti nell'Italia del Seicento, II. Salvator Rosa (Florence, 2014), I48-9; Helen Langdon, 'A Theatre of Marvels: The Poetics of Salvator Rosa', Kunsthistorisk tidskrift, 73 (2004), I79-92.

${ }^{24}$ Paul Nelles, 'Jesuit Letters', in Oxford Handbook of the Fesuits, ed. Županov, 44-72; The Fesuit Ratio Studiorum: 4ooth Anniversary Perspectives, ed. Vincent J. Duminuco (New York, 200o); Claude Pavur, In the School of Ignatius: Studious Zeal and Devoted Learning (Boston, MA, 2019). On the genesis and development of the Ratio studiorum see Monumenta Paedagogica Societatis Iesu, ed. L. Lukács (7 vols., Rome, I965-92). The last three volumes contain the two full drafts from I586, the I59I draft as well as the I599 one.

${ }^{25}$ Robert Maryks, Saint Cicero and the Jesuits: The Influence of the Liberal Arts on the Adoption of Moral Probabilism (Aldershot, 2008).

${ }^{26}$ Anthony Grafton, Forgers and Critics: Creativity and Duplicity in Western Scholarship, 2nd edn (Princeton, 2019); Arnaldo Momigliano, 'Ancient History and the Antiquarian', Fournal of the Warburg and Courthauld Institutes, I3 (1950), 285-315. On intra-Catholic erudite squabbling and its implications see Simon Ditchfield, Liturgy, Sanctity and History in Tridentine Italy: Pietro Maria Campi and the Preservation of the Particular (Cambridge, 1995).
} 
Another general point I want to make is the degree to which so many of our narratives and counter-narratives about the making of Roman Catholicism as a world religion have been shaped by the historiography authored by the religious orders. Again, this is not a new insight. In two of his four presidential addresses on 'Great Historical Enterprises', a former president of this society (I957-6I), David Knowles, spoke eloquently of the contribution made by such great seventeenth-century scholars as his Benedictine forebear Jean Mabillon (I632-I707) to the science of diplomatics, and by the Jesuit Bollandists to textual scholarship in general as authors and editors of the most comprehensive collection of saints' lives ever undertaken, the multi-volume Acta sanctorum which began publication in Antwerp in $1642 .{ }^{27}$ In the case of this last lecture, as an introduction to the Bollandists Knowles's sprightly account has never been bettered.

However, it is remarkable how many still treat such products of ecclesiastical erudition as mines of information rather than as rhetorical constructs. This is despite Luke Clossey's warning that we need to remember that Jesuit authors were not anthropologists manqués, but labourers in the vineyard of the Lord whose absolute priority was the saving of souls. ${ }^{28}$ Moreover, the important work of such scholars as Ines Zupanov and Joan-Pau Rubiés has drawn attention to the varied purposes of the Jesuit 'art of describing' in Southeast and East Asia, and Pascale Girard's case study of accounts of Christian missions to China, the Philippines, Japan and Cochinchina has conclusively shown us that such histories are unavoidably textual constructs, which were subject not only to the constraints of genre and shaped by the expectations of their readers, but also written by authors who were not historians in the modern sense of the term, and so should not be read, naively, as 'protohistories' of the missions but rather as 'mythical' or at least symbolic narratives. ${ }^{29}$

In this regard, it is highly appropriate that the subject of this article, Daniello Bartoli, did not self-identify as an historian. Far from it, he referred to his multi-volume, though uncompleted, history of the Society, which he had only undertaken in I648 at the specific behest of Vincenzo Carafa, the superior general, as 'this long and utterly tedious

\footnotetext{
${ }^{27}$ M. Knowles, 'Great Historical Enterprises, I. The Bollandists', Transactions of the Royal Historical Society, 8 (I958), I47-66; Knowles, 'Great Historical Enterprises II. The Maurists', Transactions of the Royal Historical Society, 9 (I959), I69-87.

${ }^{28}$ Luke Clossey, Salvation and Globalization in the Early Jesuit Missions (Cambridge, 2008), 8.

${ }^{29}$ Ines G. Županov, Disputed Mission: Fesuit Experiments and Brahmanical Knowledge in I7thCentury India (Oxford and New Delhi, 200r); Joan-Pau Rubiés, Travellers and Cosmographers: Studies in the History of Early Modern Travel and Ethnology (Aldershot, 2007); Pascale Girard, Les religieux occidentaux en Chine à l'époque moderne: Essai d'analyse textuelle comparée (Paris, 200o).
} 
chore' $3^{\circ}$ A brief consideration of his career, on the one hand, and his published writings on the other, should help us to see not only where Bartoli was coming from but also the uses of history as he saw them. It is highly significant that he spent the first two decades of his career in the Society as a teacher, particularly of rhetoric, and then as a preacher. It was only after Bartoli's single adventure that even begins to compare with the trials and tribulations of so many of his missionary protagonists his shipwreck off Capri - that the Jesuit is 'nailed [to his desk] in Rome' ('inchiodato in Roma'), to borrow his own turn of phrase, and told to set down the adventures of others at second hand (though he certainly put his direct experience of shipwreck to good use in his many descriptions of the storms endured by his brothers en route to Goa and the Far East)..$^{\text {I }}$ It was only in his 'free time', so to speak, that he would be able to devote attention to writing treatises more to his taste.

Perhaps the most famous of these treatises in his lifetime, The Man of Letters Defended and Emended, published in I645, a year before his shipwreck altered the trajectory of his career so dramatically, was something of a baroque bestseller, enjoying numerous Italian editions and translations - eight in the year of publication alone - and earning the approbation not only of that trophy Catholic convert and bluestocking Queen Christina of Sweden, but also of the artist Salvator Rosa to whom the (pirate) Florentine edition of the work of that year was dedicated by its printer. ${ }^{2}$ This critical success serves to remind us that being a member of the Society of Jesus was far from incompatible with literary fashionability. The treatise argued for the virtues of solitude and the need for the true man of letters to cultivate otium and retreat from the life and business (negotium) of the court. Like those avatars of heroic freedom the ancient philosophers of antiquity such as Diogenes and Crates, who are presented by Bartoli in intensely visual language as 'astounding curiosities' who 'still live, still talk, still teach' by means of their sayings and actions, the man of letters should scorn earthly

$3^{0}$ 'Quando piacerà a Dio ch'io la [Istoria] venga finita, applicherà l'animo e la penna a qualche libretto come soglio, per sollevamento dell'animo da mia lunga e incredibilmente noiosa factica' (emphasis added). From a letter from Bartoli to Giovanni Giacomo Brunelli, I5 July 1662. See Lettere edite ed inedite dal padre Daniello Bartoli e di uomini illustri scritte al medesimo, ed. G. Boero (Bologna, I865), 31.

${ }^{3 \mathrm{I}}$ Bartoli to Giovanni Giacomo Brunelli, 3 February 1657 , in Lettere edite ed inedite, ed. Boero, 27.

${ }^{32}$ Dell'Uomo di lettere difeso et emendato parti due (Florence, I645). Queen Christina asked to see a copy in Stockholm in the early i65os even before she converted and travelled to Rome. See John J. Renaldo, Daniello Bartoli, a letterato of the Seicento (Naples, 1979), 7r. Translations appeared in French (I65I), German (I654), English (I660), Latin (I672) and Spanish (I678). There was also a belated Dutch translation (I722). See Daniello Bartoli, The Man of Letters Defended and Amended, ed. and trans. Gregory Woods (New York, 2018), vii-viii. I am most grateful to Dr Woods for sending me a copy of this valuable edition. 
possessions and liberate himself from ambition and fear. 33 Here the world was a theatre of marvels, full of terrible beauty. Through his artful use of striking paradoxes - 'orrida bellezza' (horrible beauty) is just one of many - and arresting visual language, Bartoli unsettled his audience's perception of the world, thereby provoking awareness of its deeper, underlying unity.

Moreover, it was a world in which geography was to be considered as complementary to history, in the same way that the tongue (history) let the eyes (geography) speak. ${ }^{34}$ Without geography the earth was but a dark planet since one did not know where events were taking place. 35 As a sometime pupil of the astronomer and natural philosopher Ricciotti, we should not be surprised at Bartoli's interest in the natural world not simply as a source of metaphors, for he was also the author of several scientific treatises. One of these, on atmospheric pressure, referred to the debate between Robert Boyle and others over the existence of the vacuum. ${ }^{6}$ In this treatise Bartoli was concerned, above all, with not compromising the orthodox, Aristotelian position which denied the possibility of the vacuum. Throughout, he was content to cite the experiments of others (though we know he owned a copy of Boyle's works and disagreed with them). 37 The other two treatises dedicated specifically to natural history were on acoustics and on the freezing properties of water. ${ }^{38}$ According to John Renaldo, Bartoli's three scientific treatises which, as we have just seen, were devoted to ice (touch), the vacuum (sight) and to sound (hearing), were part of a single project to attack those, such as Boyle, who concluded that empirical method proved the existence of atoms and thereby subordinated reason to cognition:

By the last half of the Seicento the role of right reason in the conversion of nonChristians served as the basis for much of the Society's missionary role. In the case of the Chinese particularly, the Jesuits argued in their official histories of the mission

${ }^{33}$ Helen Langdon, 'Philosophy and Magic', in H. Langdon with X. Solomon and C. Volpi, Salvator Rosa (London, 2010), I94-201, at I95-6.

34 'Cieca dunque è l'Istoria, se a veder la terra le manca il lume della Geografia. Altresì la Geografia, se l'historia non le dà che parlare, da sè sola è mutola'. Bartoli, La Geografia trasportata al Morale (Rome, I664), but consulted here in the collected edition of his moral treatises: Delle Opere del P. Daniello Bartoli, della Compagnia del Giesu, Le Morali (Rome, I684), 392.

35 'E quanto all'Istoria, ella, senza la Geografia è come orba; così tutta al buio on sa a qual parte della terra si volgere per rinvendire il dove de' fatti, che suo mestiere è fare palese al mondo; e convenevole collocar giustamente ogni cosa a'suoi luoghi.' Bartoli, Delle Opere ... Le Morali, 39I.

${ }^{36}$ La Tensione e la Pressione disputanti qual di loro sostenga l'argento vivo ne, cannelli dopo fattone il vuoto. Discorso del P. Daniello Bartoli della Compagnia di Giesu (Bologna, I677).

${ }^{37}$ I am indebted to Antonio Clericuzio of the University of Roma Tre for discussion with me on this point.

${ }^{38}$ Del suono, de' tremori armonici e dell'udito (Bologna, I680); Del ghiaccio e della coagulazione (Rome, I68I). 
that right reason had brought the Chinese to the very portals of the Church. If man did truly learn only through experience, and Christianity was the result of the experience of the Latin west, then the Christian tradition would be significantly limited. In fact missionary activity on all levels, and not just in China, would be rendered fruitless if not foolish. 39

Ultimately, for Bartoli, atomism threatened to break the chain of God's creation by discouraging curiosity about the natural world, which, for the Jesuit, was all about linking parts to the whole. As he put it in his treatise on ice:

The world is nothing more than one great machine composed of many smaller machines so closely linked together that they work perfectly. Each of these smaller machines is composed of so many small parts, all of such a nature and working in such a way that their operation should not arouse in you curiosity about their particular nature but should rather elevate your mind to an act of philosophical wonder..$^{\circ}$

\section{IV}

So far so (relatively) straightforward it would appear. Here we have Bartoli the experienced teacher and preacher (with hinterland) who was commanded to write a history of the Society in a period when history was still seen, not as an autonomous discipline, but rather as a reservoir of stirring and striking examples to praise the good and damn the bad. This logic becomes even clearer when one takes into account that from its very beginnings the Society had been constituted in such a way as to ensure that not only would Bartoli's rhetorical talents be matched closely to the task at hand but he would be furnished with plenty of raw material through membership of a religious order for which the effective circulation of information was its lifeblood. To begin with, there was a stress from the outset on the importance of instilling into new members of the Society a sense of the order's history. Already by 1565 the Second General Congregation of the Society specified in a single decree concerning 'the manner of communicating' not only the frequency with which local superiors should write to their provincials but when both of them should write to the superior general. ${ }^{1}$

The Constitutions of the Society, published in $155^{8}$, only two years after the founder's death, required superiors of individual Jesuit houses to write weekly to their provincial who, in turn, was obliged to write to the superior general, also on a weekly basis if close, and monthly if located at a greater distance from Rome. The key figure here, and

${ }^{39}$ John J. Renaldo, 'Bacon's Empiricism, Boyle's Science, and the Jesuit Response in Italy', Fournal of the History of Ideas, 37 (I976), 689-95, at 69I.

${ }^{40}$ Bartoli, Del ghiaccio, 47 as translated in ibid., 693. I propose to discuss in greater detail in a forthcoming study the ways in which Bartoli's science informed his history writing.

${ }^{4 \mathrm{I}}$ For Matters of Greater Moment, 124-5 (decree 54). 
arguably second only to Loyola himself in shaping the Society's DNA, was Juan Alfonso de Polanco, who acted as secretary of the Society for no fewer than twenty-six years from $\mathrm{I} 547 \cdot{ }^{42}$ For Polanco the letter was the law, in a very real sense, and although the level of frequency just mentioned was soon abandoned as impracticable, a Jesuit letterwriting manual of I620 refers to at least sixteen different kinds of documents which provincials were obliged to send to Rome on a regular basis, as Markus Friedrich has noted in his important work on Jesuit governance. ${ }^{43}$ The resulting archive offers scholars to this day the opportunity to gauge the grasp as well as measure the reach of an institution which is only comparable to the archives of the papacy itself in its claim to command a genuinely global frame of reference.44 Furthermore, rectors of colleges were instructed to prepare annual catalogues of those resident, to send to their provincials who would then send them on to the superior general. These catalogues are still held in the Jesuit archive in Rome, and the more detailed ones, compiled every three years (catalogi triennales), enable us to know the number, age, origins, education, date of final vows (if applicable), state of health and ministries performed by each member of a community. 45 In a further, 'secret catalogue' (catalogus secretus) the human qualities of each member of the community were set down according to the following instructions:

Skills and qualities of each one should be described in the second catalogue, that is: talent, judgment, practical wisdom, practical experience, advancement in arts, physical appearance, and particular skills for performing the Society's ministries. $4^{6}$

${ }^{42}$ Nelles, 'Jesuit Letters'.

${ }^{43}$ Constitutions of the Society of Jesus, paras. $673^{-6}$ (pp. 326 and 328). See also M. Friedrich, 'Communication and Bureaucracy in the Early Modern Society of Jesus', Schweizerische Zeitschrift für Religions- und Kulturgeschichte, IOI (2007), 49-75, at 56; and Friedrich, Der lange Arm Roms? Globale Verwaltung und Kommunikation im Fesuitenorden, I54O-I773 (Frankfurt and New York, 2011).

${ }^{44}$ Although the date of foundation of the Vatican Apostolic Archive (AAV), formerly known as the Vatican Secret Archive (ASV), is traditionally given as I6I2, no attempt was made to create a complete index until that of Giuseppe Garampi who as prefect of the archive $\left(175^{-}{ }^{-72}\right)$ oversaw the creation of the famous 'Schedario Garampi', which he considered as a first stage in the writing of a genuinely global history of the Roman Church, entitled Orbis christianus. It consists of 80o,ooo index cards, which were stuck into I25 folio volumes in the nineteenth century and are still in daily use by scholars with the assistance of Sussidi per la consultazione dell'Archivio Vaticano. Lo schedario Garampi-i registri vaticani - i registri lateranensi - le 'rationes camerae' - l'archivio consistoriale, new edn, ed. G. Gualdo (Vatican City: Archivio segreto, I989), part I.

${ }^{45}$ E. Lamalle, 'Les catalogues des provinces et des domiciles de la Compagnie de Jésus', Archivum Historicum Societatis Iesu, I3 (I944), 77-IoI.

${ }^{46}$ 'In secundo catalogo dotes et qualitates uniuscuiusque describantur, videlicet: ingenium, iudicium, prudentia, experientia rerum, profectus in litteris, naturalis complexio, et ad quae Societatis ministeria talentum habeat.' Institutum Societatis Iesu (3 vols., Florence, I892-3), III, 45 . 
According to Cristiano Casalini, although catalogues of individual members had been kept by the Benedictines, the Franciscans and Dominicans, such a systematic attempt at personality profiling, based on the assumption that the body and soul were connected, was new. It was also consonant with Ignatian spirituality, since the Spiritual Exercises, in the words of Casalini, 'affirmed the idea of psychosomatic unity as the fundamental lens through which to examine the individual'.47 Although the physician-philosopher Galen (I29-c.216 CE) had bequeathed to the West (via Arabic) the doctrine of the four humours blood, phlegm, yellow and black bile - to explain temperament, it was left to the Spaniard Juan Huarte de San Juan, in his treatise Examen de ingenios ('Examination of talents') of 1575 , to argue how these humours also determined an individual's particular skills, and to the Jesuits to adopt the doctrine wholesale, as reflected not only in their catalogues but also in their rules for study, the Ratio studiorum (I599).

Here is the relevant information about Bartoli which was collected for one such entry into the triennial catalogue dating from 1633 , when he was just twenty-five and living and working in the prestigious Jesuit college in Parma, which enjoyed particularly generous support from the ruling Farnese dynasty. Going from left to right, it judges Bartoli according to the following qualities: first, Ingenium (intellectual capabilities) - 'Bonum'; second, Iudicium (judgement) - 'Bonum'; third, Prudentia (prudence) - 'Moderate'; fourth, Experientia reru $[\mathrm{m}]$ (life experience) - 'Esigua' (Limited); fifth, Profectus in litteris (educational capabilities) - 'Optimus [in the] Hum[anitates]'; sixth, Naturalis complexio (temperament) - 'Melancholia'; and finally, seventh, Aptus ad omnia fere societatis ministeria - he has aptitude for almost all ministries/duties/ roles in the Society (Figure 3).

Given the apparent breadth of Bartoli's intellectual capabilities, it can perhaps be of little surprise that no fewer than five attempts to be sent on missions 'to the Indies' were declined. Bartoli was one of the many who wrote to the father general seeking to be sent to the Indies; there are over I 4 ,ooo such letters extant dating from before the suppression of the Society in $\mathrm{I} 773$, whose writers were disappointed. Bartoli's potential as teacher, preacher, writer and administrator was clearly regarded as being too valuable to let him be sent overseas, where the mortality rate on the voyage from Lisbon to Goa could be as high as $5^{0}$ per cent. $4^{8}$

\footnotetext{
${ }^{47}$ For this and what follows see C. Casalini, 'Discerning Skills: Psychological Insight at the Core of Jesuit Identity', in R. Maryks, Exploring Fesuit Distinctiveness: Interdisciplinary Perspectives on Ways of Proceeding within the Society of Jesus (Leiden and Boston, MA, 2016), I89-2II.

${ }^{48}$ Five letters addressed from Bartoli to the Superior General Muzio Vitelleschi (I563I645) survive from a seven-year period (February I627 to October I635): ARSI, F.G. $73^{8}$,
} 


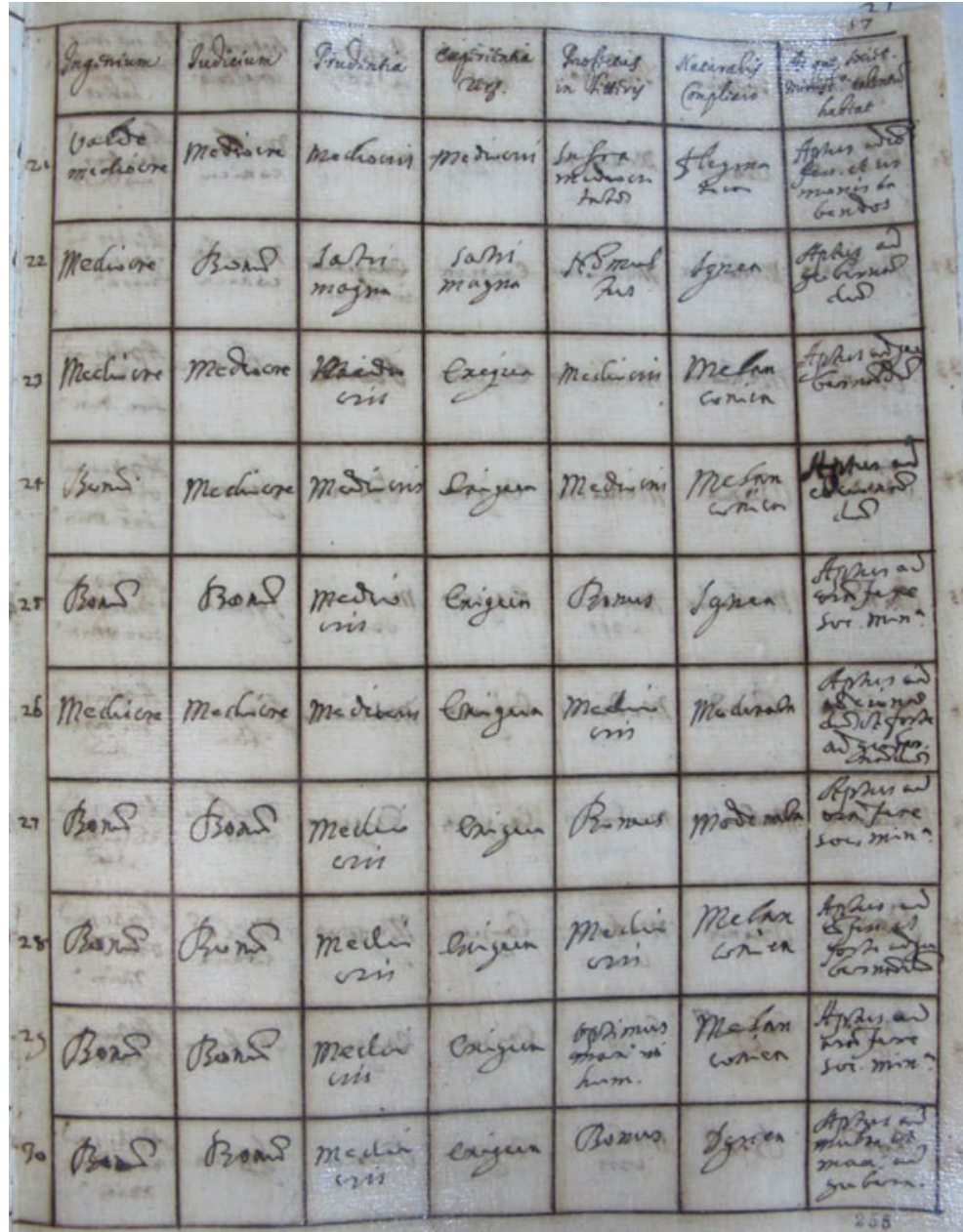

Figure 3. Archivum Historicum Societatis Iesu (ARSI), Ven. 39I, fol. 255r. Bartoli is the penultimate listed, number 29. Image courtesy of ARSI.

fols. $7 \mathrm{r}$ and $\mathrm{I} 89 \mathrm{gr}$ F.G. 739, fols. I79r and 239r; F.G. 74o, fol. $363 \mathrm{r}$. These have been printed in Lettere edite ed inedite, ed. Boero, I-7. Unusually, we also have Vitelleschi's replies, which have been printed in Lettere edite ed inedite, 8I-3. For the mortality rate on board ship from Lisbon to Goa see L. Brockey, Fourney to the East: The Jesuit mission to China, I579-I724 (Cambridge, MA, and London, 2007), 37 . 
It is within this context that we need to interpret the insistence of the founders of the Jesuits from the outset not only on the importance of history to the Society's very identity but also on the desirability of knowledge about the foreign cultures encountered by its members on overseas mission. This is laid out by the Constitutions:

Sufficient information about the Society should be given to them [those admitted to probation] at this time, both by direct conversation and from a study of its history, as also from its principal documents both older ones (such as the Formula of the Institute, the General Examen and the Constitutions or experts from them) and more recent ones [Norms, $\left.25 \$_{4}\right] \ldots$ Those who are in charge of formation should take care that our members, especially in the period immediately after the novitiate, become familiar with the sources of the spirituality of the Church and the Society, with its history and traditions, and that they study them with a view toward their own progress and the progress of others. [Norms, 69 §I] (Emphasis added)49

Although the composition of the Constitutions was complete by the time of Loyola's death in 1556 (having undergone three successive stages in 1547 , I550 and I553) and received papal approval in $155^{8}$, they only took on a more complete form in I635, when the initial framework was published together with explanatory glosses and norms in a volume called the Institute of the Society of Jesus (Institutum Societatis Iesu), a document which was updated several times in the eighteenth and nineteenth centuries. $5^{\circ}$ I draw your attention particularly to the fact that members of the Society were expected to internalise their sense of history from conversation as well as study, which reminds us that just as their prowess in Ciceronian Latin was a spoken skill so was their capacity to debate and argue essentially oral. Works such as Bartoli's Istoria were to be heard and not just read. $5^{5}$ As Jennifer Richards has rightly insisted, we must learn to listen to early modern texts and, as scholars, be much more voice-aware. The Age of Print did not silence the written word. Rather it 'aligned eye, tongue and ear' and 'allowed oral literacy to flourish' as never before..$^{2}$

${ }^{49}$ Constitutions of the Society of Jesus, 75, I45.

${ }^{50} \mathrm{My}$ understanding of the development of the Constitutions and their relationship with the Institutum derives from Markus Friedrich, Jesuit Organization and Legislation: Development and Implementation of a Normative Framework', in Oxford Handbook of the Fesuits, ed. Županov, 23-43, at 24-7.

${ }^{5}$ See, for example, the letter of Bartoli to Giovanni Girolamo Brunelli (3o December I65I), in which the Jesuit refers to: 'la Vita di Sant'Ignazio, che m'hanno onorato di leggere in pubblico'. Lettere edite ed inedite, ed. Boero, I3.

${ }^{52}$ Jennifer Richards, Voices and Books in the English Renaissance: A New History of Reading (Oxford, 20I9), I0. 
The second volume of Bartoli's Istoria, after that on the Society's founder, was published a few years after the life of St Ignatius, in I653. It was dedicated to Asia, and the first four of its eight books were almost entirely given over to the figure who, not only in Bartoli's eyes, was seen in many ways as the co-founder of the Society, the Basque nobleman Francis Xavier, and his missions to India, the Moluccas and Japan. Bartoli availed himself extensively of the resources available to him in Rome courtesy of the Jesuit habits of record-keeping, as first Josef Wicki and now Elisa Frei have shown in their exhaustive editorial work which one can consult in the latest edition, based on that of I667.53 However, in fact 'the Dante of baroque prose', as the major romantic poet and essayist Giacomo Leopardi (1798-1837) later called Bartoli, was true to this epithet and made extensive use of such sources as the numerous letters and testimonies of witnesses from Xavier's beatification and canonisation trials (including the all-important summary reports made on behalf of the auditors of the Rota, the highest papal court) as raw material for his own artful elaborations.54

Again and again, Bartoli can be seen to prefer narrative sources over archival ones; not because he did not value the latter, but simply because his purpose was different. He set this out in a very brief, undated document, probably written around the time of the composition of the volume on Asia.55 This is the closest we can get to knowing for sure what he thought he was doing and is entitled simply: 'How to write the history of the Society'. This two-sided document includes such statements as the following: 'If we are to do justice to the subject; one needs to break free of Chronology ... in order to consider a mission, a life, a persecution [without breaking the narrative thread] ... For this one needs to arrange the history according to place [geographically rather than rhetorically speaking].' Bartoli explicitly distinguished his approach from the scrupulously chronological one which, as has already been seen, had been undertaken by Niccolò Orlandini and Francesco Sacchini and was being continued by Pierre Poussine. Bartoli noted how all three

${ }^{53}$ Daniello Bartoli, Istoria della Compagnia di Gesù. L'Asia, ed. Umberto Grassi and Elisa Frei (2 vols., Turin, 20I9); Josef Wicki, 'Vorarbeiten für eine geplante kritische Ausgabe der Asia des P.D. Bartoli SJ', Aufsätze zur portugeisischen Kulturgeschichte, I8 (I983), 202-43; Wicki, 'L'Asia I, libro 7 sull'India (I553-I572)', in Daniello Bartoli storico e letterato (Ferrara, I986), I7-30.

${ }^{54}$ Bartoli, L'Asia, vol. I, e.g. II, 33, 34I, 423-4, 46I, 5 or.

55 'Del modo di scrivere l'istoria della Compagnia, manoscritto autografo di Daniello Bartoli', ARSI, Epp. NN. 96 , fols. I8r-I9v. A full transcription, translation and commentary of this important document is currently in preparation. The only published version, by Maria Brutto Barone Adesi ('Daniello Bartoli storico', Rivista di storia di storiografia, I (I980), 77-IO2) is unreliable and misleading. My thanks to Elisa Frei for her transcription. 
took full advantage of the steady stream of letters, above all the quarterly ones which arrived regularly at the Jesuit headquarters in Rome, from outside Europe. He also noted how these authors all wrote chronology, not history, sacrificing thereby the coherence of events to the sequence of time and, in the process, fragmenting the narrative into tiny pieces. As Bartoli concluded: 'What seems to me to be novel, and for this reason worth doing, is that there is no other religious order where one can begin with its origins $\ldots$ and then go on to offer histories of the four parts of the world ...'5 5

So, for Bartoli, while there are numerous references to letters in his history, they performed another function that was not just about their content but their importance to the story being told; firstly to the protagonists themselves and then to their audiences in the Old World. To limit myself to his volume on Asia, Xavier was not just a writer of letters but a grateful receiver of them. Basing himself, in part, on one of Xavier's own letters, Bartoli notes how the missionary saint read and reread those he received from his brothers in Europe, before kissing them a thousand times, and soaking them with his tears as he recalled those who had sent them. ${ }^{57} \mathrm{He}$ even cut out the signatures from the letters and wore them, as if they were relics, around his neck..$^{8} \mathrm{On}$ another occasion, Bartoli mentioned that on his travels Xavier carried just three things with him, around his neck, which were collected together like a reliquary. They were a bone fragment belonging to the Apostle to Asian Christianity, St Thomas; an autograph signature of Ignatius Loyola; and Xavier's profession of faith written in his own hand.59 Elsewhere, on several occasions, Bartoli referred to the consolation which letters with their tales of missionary derring-do gave to their confreres in Europe who were also experiencing difficulties. ${ }^{60}$

\section{VI}

Turning to Bartoli's treatment of the Jesuit mission to Japan, which appeared in I66o, ten years after his first volume on Ignatius but after

\footnotetext{
${ }^{5}{ }^{6}$ 'Che se ciò sembra nuovo, nuova ancor'è la cagione di farlo; non vi essendo altra Religione che possa cominciare da suoi principii ... historie che per le quattro parti del mondo come la Compagnia'. ARSI, Epp. $\mathcal{N N}$. 96, fol. I9v.

${ }^{57}$ Bartoli, L'Asia, vol. I, I36-7; The Letters and Instructions of Francis Xavier, trans. and ed. M. Joseph Costelloe (St Louis, I992), I3o.

$5^{8}$ 'A quante lettere gli scrivevano i nostri da Europa e dall'India, tagliava i nomi delle sottoscrizioni, a portavali al collo, come reliquie di santi uomini, e come dolci memorie da consolarsi.' Bartoli, L'Asia, vol. I, 533 .

59 ‘ $\ldots$ un minuzzolo d'osso dell'apostolo $\mathrm{S}$. Tomaso primo padre della cristianità orientale; uno sottoscrizione del santo padre Ignazio... e la sua professione religiosa, scritta di proprio pugno'. Bartoli, L'Asia, vol. I, 534 .

${ }^{60}$ Bartoli, L'Asia, vol. II, I37-8, I54, 228.
} 
only two of the three editions of that on Asia which were published in I653, I656 and I667 (the last of these incorporating a new section on the Mission to the Mughal emperor Akbar, which had been separately published in I663), the historian had already described Japan extensively

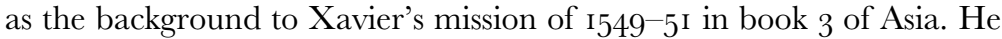
was careful also to emphasise the correspondences which he believed existed between Japanese and Christian society. In particular, he followed the widespread tendency in European accounts of the time to project onto the Japanese a 'religion' which was identifiably 'Western', with its parallel hierarchy, monasteries, monks, temples, processions and sacred books. In this he was of course following, albeit in a more attenuated fashion, one of the very earliest reports about Japanese religion given by the French linguist and mystic Guillaume Postel in his Des mervailles du Monde of ${ }^{1553}$, in which the French scholar argued that 'the Japanese were basically Christians, albeit ones who had forgotten much of the True Gospels'. ${ }^{1}$ As it happened, the Japanese, in their own way, returned the compliment by regarding Christianity as deformed Buddhism; a supposition which appeared to be confirmed by the fact that the missionaries also came from India, which had been the source of Buddhist teachings almost precisely a thousand years before. However, as Joan-Pau Rubiés has shown in his subtle and searching analysis of the so-called Yamaguchi disputations of September I55I between Xavier together with some of his fellow missionaries and some Buddhist monks, one is speaking of a dialogue only in the sense of finding some common ground for disagreement. ${ }^{62}$ Moreover, in the course of the conversations, the Sorbonne-trained Xavier was careful not to analyse the diversity within Buddhism as in any way analogous to the diversity within Latin Christendom.

For a broader context, one needs also to bear in mind that between $159^{8}$ and 1650 no fewer than ninety-one martyrological works on Japan had been published in Western Europe (including two plays by Lope da Vega), so that Bartoli had precedent when he moved on to write his volume of the history of the Society in England after those on Japan (I66o) and China (I663). ${ }^{6}$ The second part of Pedro de Ribadeneira's immensely popular Historia ecclesiastica del cisma del Reino di Inglaterra had explicitly juxtaposed the flourishing state of Japanese

\footnotetext{
${ }^{6 \mathrm{r}} \mathrm{J}$. Ānanda Josephson, The Invention of Religion in Fapan (Chicago, 2012), 59.

${ }^{62} \mathrm{~J}$.-P. Rubiés, 'Real and Imaginary Dialogues in the Jesuit Mission of Sixteenth-Century Japan', Fournal of the Economic and Social History of the Orient, 55 (2012), 447-94.

${ }^{63}$ Rady Roldan-Figueroa, The Martyrs of Japan: Publication History and Catholic Missions in the Spanish World (Spain, New Spain, and the Philippines, I597-I700) (Leiden, 202I). See also Rady Roldán-Figueroa, 'Father Luis Piñeiro, S.J., the Tridentine Economy of Relics, and the Defense of the Jesuit Missionary Enterprise in Tokugawa Japan', Archiv fur Reformationsgeschichte/Archive for Reformation History, IOI (2010), 207-30.
} 
Christianity with the deplorable state of that in England as early as I593; a comparison which likely provoked Bartoli to refer to England, in a letter, as 'Europe's Japan'. ${ }^{64}$ Bartoli began, literally, at the beginning, with his account of how the Japanese themselves described the beginning of the world - their Genesis story, if you like. He went on to describe its geography and its climate, which he reported was similar to that of Sicily though much windier, before giving what was overall an unambiguously positive assessment of the Japanese people. He admired Japanese eloquence and emphasised their fierce code of honour. Compared with the Christian converts in India, the Japanese were, on the whole, much more constant and indeed tenacious in their new faith. Indeed, Bartoli never lost the opportunity to emphasise the nobility in both spirit and blood of the Japanese martyrs, both young and old. This detail alone strongly suggests that the audience was intended to be the noble pupils attending Jesuit colleges; the same students who would also take part in the famous Latin plays, many of which were on subjects taken from the most heroic, early-Christian period of history. The longest two entries in the index to the first edition of Giappone are on 'Japanese women memorable for their virtue' (their Christian names constitute a veritable roll call of early Christian heroines: Massentia, Marta, Tecla, Susanna, Monica, etc.) and on 'Extraordinary torments given to [Japanese] Christians'. The list of tortures, which ran to one and a half columns, left little to the imagination, and the sufferings of several Japanese martyrs made their way back to Europe in such works as Matthaeus Tanner's martyrology of the Society. ${ }^{6}$ Bartoli's narrative ends with the expulsion of the Jesuit missionaries more or less one hundred years after Xavier's arrival.

\section{VII}

This is more or less the chronological end point too of Bartoli's third part of the Asian mission, and the next to be published, in I663, on China. ${ }^{66}$ If the volume on Japan came to resemble a contemporary updating of the Roman martyrology, with its mainly Japanese together with a few Jesuit martyrs standing in for their late antique prototypes, and successive

\footnotetext{
${ }^{64}$ Pedro de Ribadeneyra, Segunda parte de la historia ecclesiastica del scisma de Inglaterra (Alcalá de Henares, I593), bk III, ch. 20; Letter to Giovanni Giacomo Brunelli, 9June I665, in Lettere edite ed inedite, ed. Boero, 32-3. There is now an English translation and critical edition by Spencer J. Weinreich: Pedro de Ribadeneyra's 'Ecclesiastical History of the Schism of the Kingdom of England': A Spanish Fesuit's History of the English Reformation (Leiden, 2017).

${ }^{6}$ Matthaus Tanner, Societatis Iesu, usque ad sanguinis et vitae profusionem in Europa, Africa, Asia et America contra gentiles, mahometanos, judaeos, haereticos, impios pro Deo Fide Ecclesia pietate (Prague, I675), 207-432 (for Jesuit martyred in Asia).

${ }_{66}$ Bartoli, Dell'historia della Compagnia di Giesu. La Cina. Terza parte dell'Asia (Rome, I663).
} 
shoguns for pagan Roman emperors, Bartoli's narrative on the Jesuits in China was very different. Notwithstanding the chaos that accompanied the transition from the Ming to Qing dynasties in the middle decades of the seventeenth century, which during the final years of the regency of the Kangxi emperor (reigned I66I-I722) had effectively led to the Jesuits being under house arrest, Bartoli's tale was upbeat - and indeed by the end of the i66os the fortunes of the Society were to be spectacularly reversed when the Flemish astronomer and mathematician Ferdinand Verbiest (I623-I688) was able to take advantage of the opportunity given to him by the young emperor to demonstrate the superiority of Western astronomy over its Chinese counterpart to be appointed director of the Imperial Mathematical Tribunal and become sometime tutor to the longest-serving and arguably most successful ruler in Chinese history. However, this postdated Bartoli's account, which instead focused on the success of Matteo Ricci's mission.

This focus was for the very obvious reason that Bartoli had by his side Ricci's account of his time in China, which was only publicly available then in a Latin rendition, published in I6I5, that had been translated out of the vernacular by the Flemish Jesuit Nicolas Trigault and used by him to help raise money, very successfully as it turned out, for the Chinese mission. However, on several occasions in his text, Bartoli insists on the fact that Ricci, not Trigault, was the true author of this text, which remained unpublished until the twentieth century. ${ }^{67}$ As is well enough known, the account of the Jesuit mission to China as mediated by Matteo Ricci is one of hard work mastering the Confucian classics and the art of Chinese composition, and small setbacks mostly orchestrated by imperial officials jealous of the Jesuit's talents. It reached a fitting conclusion with Ricci's transformation into a silk-clad honorary member of the Chinese literary elite, known as $\mathrm{Li}$ Madou, and his burial consisting, at the emperor's insistence, of an uneasy marriage of Confucian and Christian rituals. ${ }^{68}$

In this volume, Bartoli gave free rein to his interest in geography and astronomy, describing in some detail not only the enormous size of the Chinese empire, but also its corresponding wealth and the sophistication of its mandarin elite. Bartoli's admiration centred on the figure of Confucius, whose ethical teachings and their focus on ceremony, obedience and order sustained a European-wide Sinophilia until at least the

\footnotetext{
${ }^{67}$ For an excellent discussion of Trigault's 'curated' translation and its purpose see Nicholas Lewis, 'Revisiting De Christiana Expeditione as an Artefact of Globalisation', Itinerario, 45 (202I), 47-69.

${ }^{68}$ Nicholas Standaert, The Interweaving of Rituals: Funerals in the Cultural Exchange between China and Europe (Seattle, 2008), ad indicem.
} 
mid-eighteenth century. The only fault that Bartoli could see in the Chinese was their ignorance that there was anything worth knowing outside their vast realm: which was why Ricci's diplomatic success in showing the emperor his map of the world without provoking imperial fury is surely the high point in his account. Given Bartoli's own interest in scientific instruments, clearly visible in his frequent deployment of astronomical metaphors, and his interest in navigation displayed particularly in his first volume on the missions in Asia (which may have its origins in the fact, as has been noted, that he had been a colleague of the astronomer Giovanni Battista Riccioli in Bologna), it is strange that so little was made of the role played by these skills in securing imperial favour for the Jesuits in China. There is, for example, no reference whatsoever to the German Jesuit, Adam Schall von Bell (I599-I666), who oversaw modification of the Chinese calendar under the last Ming emperor and also skilfully managed to ingratiate himself with the founder of the Qing dynasty, the Shunzhi emperor, who made him director of the Imperial Observatory.

\section{VIII}

The final two volumes of Bartoli's history of the Society were on Europe - England (I667) and Italy (I673). He does not appear even to have begun to work on collecting material for the volume which had been envisaged on the Americas. I have already analysed the volume on England at some length elsewhere; suffice it to say here that it was very different from all the others in two respects: first, its deployment of many more primary documents and, second, its tight focus on proving the compatibility of loyalty to the papacy with loyalty to the English crown. ${ }^{69}$ Accordingly, it concentrated overwhelmingly on the reign of Queen Elizabeth and the heroic martyrdom of several Jesuit missionaries, most famously Edmund Campion (I540-158I). The volume on Italy was scarcely less polemical and defensive, although the focus here was on the doctrinal orthodoxy of the Jesuits. Much space was given to their contribution to the deliberations of the Council of Trent including, crucially, the discussions which specifically related to Justification. Attention was also paid to the positive contribution made by the Society by means of their schools and colleges as well as their missions to the 'Other Indies'; that is to say, the backwoods bereft of adequate religious instruction, where priests were dressed no differently from their peasant parishioners with whom they worked side-by-side in the fields to support their wives and children. Bartoli's example here is Silvestro Landini's mission to

\footnotetext{
${ }^{69}$ Ditchfield, 'Limits of Erudition', $233-7$.
} 
Corsica, which the Jesuit famously compared to India in a letter to Loyola. ${ }^{\circ}$ As with the volume on England, that on Italy also had a narrow chronological focus: beginning with Loyola's arrival at the gates of Rome in 1537 and ending with the election of Francisco Borja as superior general in 1565 .

A much better-known treatment than Bartoli's of the Jesuits as missionaries to all four parts of the world, with which I draw this article to a close, is Andrea Pozzo's dizzying fresco, 'The worldwide mission of the Society of Jesus'. This covered the enormous nave ceiling of S. Ignazio in Rome, a church that was physically integrated into what remained the largest education complex in Western Europe until the nineteenth century, the Collegio Romano in central Rome. The church of S. Ignazio's prominent role in the ceremonial and liturgical life of the students at the Society's pre-eminent educational establishment made it even more central to the daily routine of the many future Jesuit missionaries who studied or taught there than the Society's mother church located less than 500 metres away. Pozzo, who was incidentally a temporal coadjutor, i.e. a lay brother in the Society, and so would likely have been very familiar with Bartoli's narrative from countless communal meals in the refectory, carried out work on the fresco between I69I and I694, in the decade after the writer's death. This image will likely be known even to those readers who don't work on either the Jesuits or the Protestant or Catholic Reformations, since it has become the 'go-to' image for any publisher, author or lecturer who wants a striking image to stand for the making of Roman Catholicism as a world religion in the early modern period. Indeed, Pozzo described it himself in the following terms:

My idea in the painting was to represent the works of St Ignatius and of the Company of Jesus in spreading the Christian faith worldwide. In the first place, I embraced the entire vault with a building depicted in perspective. Then in the middle of this I painted the three persons of the Trinity; from the breast of one of which, that is the Human Son, issue forth rays that wound the heart of St Ignatius, and from him they issue, as a reflection spread to the four parts of the world depicted in the guize of Amazons ... These torches that you see in the two extremities of the vault represent the zeal of St Ignatius - who in sending his companions to preach the Gospel said to them: 'Go and set the world alight (Ite, incendite, infiammate omnia), verifying in him Christ's words (Luke I2:49): 'I am come to send fire on the earth; and what will I but that it be kindled? (Ignem veni mittere in terram, et quid volo nisi ut accendatur). ${ }^{3}{ }^{1}$

${ }^{70}$ Bartoli, Dell'Istoria della Compagnia di Giesu. L'Italia. Prima parte del Europa (Rome, I673), $255-9$.

${ }^{71}$ Evonne Levy, Propaganda and the Fesuit Baroque (Berkeley and Los Angeles, 2004), I5I. Pozzo's explanation may be found in the pamphlet Breve descrittione della pittura fatta nella volta del tempio di Sant'Ignazio scoperta l'anno MDCXCIV per la festa del medesimo santo (Rome, I694), which can be viewed at https://archive.org/stream/brevedescrittionookoma\#page/2/mode/2up, last accessed 2 April 202I. My thanks to Professor Levy for directing 
I hope that this article has managed to convince the reader that even if they cannot disagree with Pascal, they can agree that Bartoli's equally polemical, if more various, word-painting has been at least worth the detour. It was apparently said of Bill Haley and the Comets' famous hit record, 'We're Gonna) Rock around the Clock', first issued in I954, and which inspired this article's title, that it could subsequently be heard playing on jukeboxes in the four corners of the globe. $7^{2} \mathrm{I}$ am sure that Bartoli would not have been displeased with such a comparison: Bartolum sonant.

me to the location of this very rare pamphlet. Save for the biblical passage, which is taken from The Vulgate Bible, 6: The New Testament, Douay-Rheims Translation (Cambridge, MA, and London, 2013), 389, the translation is Levy's.

${ }^{72}$ Although, arguably, this only happened some two decades later when the song opened the double LP of the soundtrack to the film American Graffiti (1973). 